\title{
異なる専門分野を通して育成される思考力
}

\author{
道田 泰司 \\ (琉球大学教育学部) \\ key words : ジェネリック・スキル, 大学教育, 専門分野
}

近年，学士力や社会人基礎力，キーコンピテンシーなどとい った言葉で，大学で身につくべき力について論じられている。 大学で身につくべき力には大きく分けて，専門の知識や技能と 一般的な技能(generic skills)があり，思考力などが一般的な技 能に含められている。

しかし「一般的」とはいっても，どのような思考力が，どの ようなプロセスを経てどのように育成されるかは，専門分野に よって大きく異なるのではないかと考えられる。

本研究は，いくつかの専門分野において，どのような思考力 が育成されているのか，教員側と学生側の双方にインタビュー することにより検討することを目的とした。

\section{方 法}

対象者 教員は, 人文科学, 社会科学, 自然科学から各 2 名, 計 6 名にお願いした。人文科学は国文学と応用言語学，社会科 学は法律学と歴史学, 自然科学は建設工学と生産環境学の教員 であった。学生は, 各教員のゼミに所属する卒業年次の学生 1 名, 計 6 名にお願いした。

手続き 教員調査では「先生の専攻分野を学ぶことで，学生 は 4年間でどのような思考力を身につけると考えているか, 学 生調査では「大学に入って思考力が高められるような授業や教 育があったか」という問いかけで, 半構造化面接を行った。所 要時間は 30〜40 分程度であった。

\section{結果と考察}

論理性 どの分野の教員にもほぼ共通して語られたのは, 卒 業研究を行い, ゼミで発表し, 論文にまとめるプロセスの中で 必要になってくる「客観的な根拠を元に, 飛躍や矛盾なく論理 的に整合的に議論が進められているか」という論理性である。

学生調査でもこのことは, すべての学生が語っていた。それ は，卒論などにおいて，「じっくり考える」「適切に分析する」 などの過程を経て, 結論を導き出して説明し文章化する際に, 筋道だっているか, などの評価が他人からなされ，自分のもの になっていくといらプロセスであった。たとえば，「「自分はこ う考えました」っていうと、例えば「何で?」と理由が追及さ れ, 理由が間違ってたり理由がいえないと突っ込まれる」,「み んなで該論し，相手への疑問や解釈の違いも遠慮せずに言い合 う」,「自分の中で伤笳道を立てて論を出してきたつもりだけど， 他人の目を通すと全然ちぐはぐ」などと, 他のゼミ生との交流 の中で論理性が高められていくことが語られていた。

以上のことから, 学生は研究活動を行う中で, 教員や他のゼ ミ生などの他者と交流し，論理性を高めているといえる。

他の可能性 分野の違いが出ているものとして, 国文学にお いては,「あなたがこう思っているのはどの言葉からか? 説明 できなければ科学ではないり, 文中の根拠が重視されている。 それに対していくつかの分野では，「統制」や「比較」という実 証科学の論理を通して他の解釈可能性が排除されていた。具体 的には，「たとえば日本語と英語を比較してみてどうか、という 形の分析ができるようになる」(言語学)，「自分が実験に失敗し て微生物が入るとするとよ゙こからなのか。それを避けるにはよ゙ うしたらいいか。意識しながら行動できるのが大事なスキル (生産環境学) という具合である。

国文学の学生は「発表を聞いて、みんなでこうなんじゃない かとか、疑問を出し合ったりとかこれはこうも考えられるんじ
やないかとかそういう話し合いりを通して自分や他人の思考を 深めており, 言語学の学生は,「ほかの人が発表するのを聞いて, 自分の研究にそういう視点も入れてみたほうがいいかもしれな いという形で「他の可能性」について考えた，と述べていた。 歴史学の学生は,「「どっちが正しいのかな」もしかしたら合致 させたような解釈ができるのかもしれない」っていうちよっと 立ち止まって一つの字と向き合うようにはなりました」と分析 的に考えるようになったことを述べていた。

以上のことから，同じ「他の可能性排除」が，その分野の方 法論（語解釈，比較，条件統制など）を通して学ばれること， また学生は, 他者との交流のなかで他の可能性の存在に気づい ているようである。

演繹的思考 法律学では, 条文という「与えられたものを適 用する技術，才なわち演繹的な思考が重視されていた。同じこ とは生産環境学でも, 植物や菌の同定において「百科事典に書 かれている記述のどれが妥当か、厳密かつ客観的な根拠」を元 に行われている。このようなことは, 文学における言葉の解釈 においても, 辞書の項目というある種の「条文」を用いて行わ れることである。

この点について触れている学生はいなかったが，演繹的に考 えることは，おそらくどの分野でも概念習得を通して身につけ られる，必須の思考力の一つと考えられる。

他者視点取得 環境建設工学では, 自分自身で体験すること や当事者にインタビューすることを通して,「体が感じることと 文献を含めたメディアを通じた知識を連続させる」ことで, 他 人の立場に立ち, それを知識や研究とつなげることが重視され ていた。学生も現地でヒアリング調査をするなかで「自分でこ う考えて、多分こうだろうなと思って言ったりするんですけど、 その人の意見は違う」と, 他人の目を通して客観的に考えるよ うになると述べていた。

直接他者と触れながら研究を行っている分野は今回の調査で は少なかったが, 他者の立場を想像できる思考力も, 分野によ っては重要なものである。

日常への般化 法律学の学生は,「ニュースとか見ていても, 法律に当てはめることはよくある」, 環境建設工学の学生は「友 達とか上話してると、家走造るときとかもそういうことが必要 になってくるんかね秏って話をしてて」と日常生活に専門で学ん だことが顔を出している。生産環境学の学生は, 日常の出来事 で疑問を持ったことを多面的に考えることについて,「そうやっ て考えることってさ、楽しいわけ」と述べていた。

視野の広がり すべての学生ではないが,「新しい知識に触れ たり今まで考えたことがなかったような話を聞くことで，考え の幅が広がった」ということを述べた学生が複数いた。

これは一般的技能としての思考ではなく，特定領域の知識を 獲得したことによる思考の広がりである。教員からはあまり述 べられなかった点である。

今回は分野, サンプルともに少ないので, 特定の分野の一般 的特徵や, 学問全体の中での様々な思考の広がりを明らかにで きるわけではなく, 特定の教員や学生の個人的な傾向も含まれ ているであろう。しかし，心理学に親しんでいる人間が想像す るような実証科学で目指されている思考だけがすべてではない ことは示されたのではないだろうか。(Yasushi MICHITA) 